\title{
The Role of The Community in Recovery of The Children's Psychic Post-Earthquake in Solok Selatan-Indonesia
}

\author{
* Yeni Putri ${ }^{1}$ and John Rey Chester ${ }^{2}$ \\ ${ }^{1}$ The Graduate Students of Geography Education, Universitas Negeri Padang, Indonesia \\ ${ }^{2}$ NGO Disaster Risk Reduction, Philippines \\ Email : yeniputri1000@gmail.com
}

*Corresponding Author, Received: Februari 10, 2019, Revised: April 10, 2019, Accepted: May 10, 2019

\begin{abstract}
The purpose of this study is to express the role of the community in the psychological recovery of children after the earthquake in Solok Selatan. The type of research used is descriptive qualitative research, with the sampling technique is purposive sampling. Data collection techniques used were interviews and documentation, then the data obtained were analyzed descriptively to present the facts encountered in the field. The results of the study are: 1) The government's role in psychological recovery of children after the earthquake in Solok Selatan was very important where the government can reduce psychologists or volunteers who have experience to help psychologically recover post-disaster children, 2) The role of NGOs in post-child psychological recovery earthquake disaster in Solok Selatan Regency namely assisting experts in the process of psychological recovery of children after an earthquake, 3) The role of costume in the psychological recovery of children after the earthquake in Solok Selatan, 4) the role of universities in children's psychological recovery after the earthquake in Solok Selatan that is helping the government, NGOs and the community in psychological recovery of children by providing entertainment, such as reading stories, playing or watching together, and 5) the role of the community in psychological recovery of children after the earthquake in Solok Selatan by sending assistance in the form of toys, clothes, foods and funds for these children. So, these five elements have a very important role and work together to be able to help the psychological recovery of children after the earthquake in Solok Selatan.
\end{abstract}

Keywords: Role of Communities, Children's Psychic Recovery, Earthquakes

\section{Introduction}

Indonesia as an archipelagic country is in a disaster-prone geographical, geological, hydrological and demographic position (Soemantri, 2012; Hermon, 2015; Hermon, 2017), and because its location is located in the equator, Indonesia is a country that has very complex potential disasters (Hermon, 2009; Hermon, 2010; Oktorie, 2017; Triyatno et al, 2018 ) Thus, natural disasters have become a part of the lives of Indonesian people, because natural events in Indonesia occur almost every day. Natural disasters that occur always result in loss of human life, environmental damage, property loss, and psychological impact. Indonesia has the potential for natural disasters in the form of floods, flash floods, droughts, volcanic eruptions, landslides, earthquakes, tsunamis, forest and land fires (Herrmon, 2012; Hermon, 2016; Oktorie, 2018). From the available data, it can be concluded that: (1) national disasters are dominated by hurricanes, floods, fires, droughts and landslides; and (2) the number of deaths is dominated by earthquakes and tsunamis (Soemantri, 2012; Hermon, 2014; Hermon et al., 2019). 
As a result of these natural disasters, causing damage and disturbing the lives and livelihoods of humans, including the psychic of a human being, which can then cause an individual or group experiencing natural disasters to suffer from Post-Traumatic Stress Disorder (PTSD). As many as 1.50 percent of the population experienced Post-Traumatic Stress Disorder (PTSD) in four years because of experiencing various events (Kinchin, 2007; Hermon, 2014; Hermon, 2016; Hermon et al., 2017; Hermon et al., 2018; Hermon, 2019). The results of research in America show that $15-43 \%$ of women and $14-43 \%$ of men experience trauma events during their lives. Children and adolescents who experience trauma events, 3-15\% of women and 1-6\% of men experience Post Traumatic Stress Disorder (PTSD) (National Center for PTSD, in Nilsson et al, 2010). From the study it was seen that women have a higher risk of developing PTSD from men, and children are one of the psychological victims of natural disasters, such as trauma or high exposure to natural disasters. Solok Selatan Regency, West Sumatra, is an area that has recently become the media spotlight after being hit by an earthquake on Thursday (28/2), the results of which have a magnitude of 5.3. BMKG noted that the earthquake was triggered by uncharted active fault activity. The earthquake shocks were felt in Solok Selatan reaching the intensity scale of V-VI MMI, Padang City III-IV MMI, Painan and Padang Panjang IIIII MMI, Payakumbuh and Lima Puluh Kota II MMI. Based on the Solok Selatan BPBD report, more than 343 houses were damaged and at least 48 people were injured in this earthquake.

According to Ehreinreich (2001); Oktorie (2018) one third of victims of natural disasters are children. This can be understood, because of the total population of a society, children are part of the population. Ehreinreich (2001); Kristian and Oktorie (2018); Hermon et al., (2018) also explained that disaster events cause psychological trauma in victims, especially in children. The impact of disasters varies for each person who experiences it. Furthermore Ehreinreich (2001) explains several factors that influence a person's vulnerability so that the risk of disaster is the higher the severity of the disaster and the level of horror experienced experience the greater the psychological effects felt. Natural disasters have a physically and socially significant impact. Given the magnitude of the impact caused by natural disasters, a comprehensive effort is needed in the implementation of disaster management both when it is happening and after a disaster ends which is at risk of physical, psychological and social problems. Therefore it is necessary to develop a community that has the ability to organize, learn and adapt in the face of disasters.

Traumatic events attack human life suddenly, and turn human life into a mess. After the event, some individuals were not sure they could live well again like before being hit by a disaster or traumatic event (Kinchin, 2007). In other words, many individuals experience severe shocks, stress, depression, and trauma after a disaster. This condition poses a serious threat to life. And it becomes even more serious or dangerous for children, partners, close relatives, or other friends (Kinchin, 2007). They need services for mental health, emotional stability, and optimism to start a new life after losing all that matters in their lives. Therefore, assistance in the form of trauma counseling services is a necessity that is no less important to prioritize.

There are two very severe psychological conditions experienced by disaster victims who escaped death. First, they bear a psychological burden that is not light because they have to live with the trauma of losing relatives and loved ones. Losing someone who is very meaningful in his life can be felt as a severe psychological blow. Not all people are able to overcome the suffering separated by force from the people they love. On the other hand, they are also losing their jobs and access to business and capital to continue their lives. Secondly, in these difficult conditions, they must be able to immediately rise up and do selfreinforcement, taking lessons from all the calamities for basic capital to start a new life from zero, even if they have to start from a minus condition. Building a life that is meaningful, requires determination of the soul and a strong belief in the greatness of God coupled with tireless efforts. Recent research reveals that the various experiences experienced by individuals can cause trauma, such as kidnapping, assault, rape, and witnessing the killing of family members, or the death of a close family member. Fourteen percent (14\%) of individuals experience trauma after being abandoned by loved ones (Weaver et al, 2003). Based on the explanation above, it can be concluded that children tend to be more susceptible to PTSD than parents. This is based on reality because children lack the ability to deal with danger compared to parents. In other words, the smaller the age of a person tends to be incapable of facing danger, and the more likely he is to experience PTSD. Based on the introduction, the purpose of this study was to reveal how the role of the government, non-governmental organizations (NGOs), costume, universities and the community towards the psychological recovery of children after the earthquake in Solok Selatan. 


\section{Method}

The type of research used is descriptive qualitative research, to express the role of the community in the psychological recovery of children after the earthquake disaster in Solok Selatan. The method used in this study is a descriptive method in the form of a description of facts found in the field which are then translated into words in the opinions of respondents, according to the research questions, then analyzed. The population in this study was the people of Solok Selatan, with sampling techniques was purposive sampling technique. Data collection techniques used were through interviews and documentation, interviews were conducted with the community and related parties to obtain data in accordance with the research objectives.

\section{Result and Discussion}

The psychological recovery of children in the aftermath of the earthquake disaster in the southern district of Solok will not run optimally if it is only carried out by one institution, but is needed by five institutions. these five institutions have a very important role and work together to be able to help the psychological recovery process of children after the earthquake in Solok Selatan. The following is a table of five institutions that play a role in the psychological recovery of children after the earthquake disaster in the Solok Selatan:

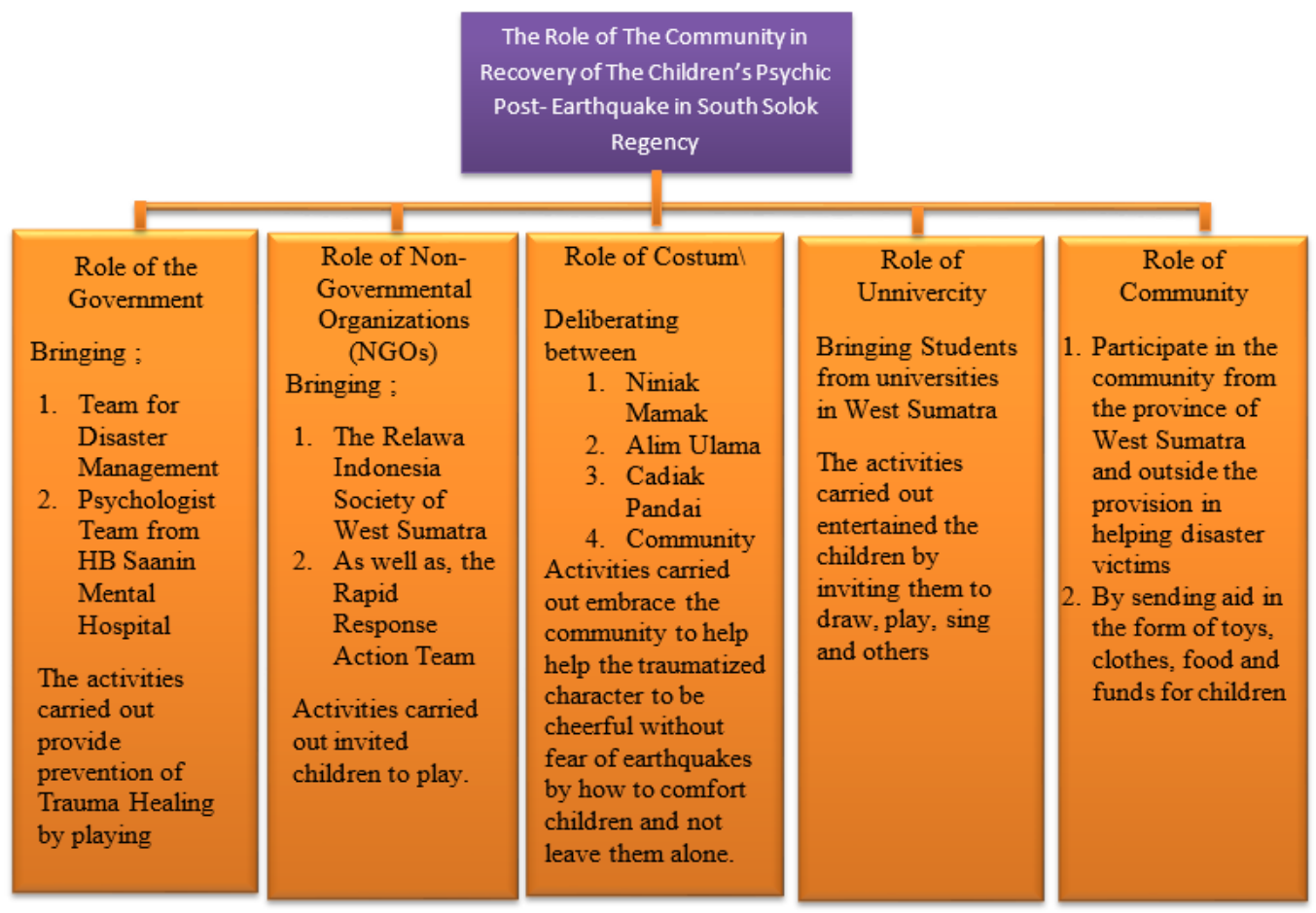

Figure 1. Five Institutions that Play a Role in The Psychological Recovery of Children After the Earthquake Disaster in The Solok Selatan

\section{The Role of the Government in the Psychological Recovery of Children after the Earthquake Disaster} in Solok Selatan

The Regulation has mandated that disasters be a joint matter and must be dealt with jointly between elements of government, business institutions and the community. The government is not the only actor in the implementation of disaster management but the Government acts as the main responsible, facilitator and regulator (Maarif, 2012). Response is important to minimize victims and optimize the ability of the community to respond. Regional disaster emergency response depends on local government. 
At the central level a National Disaster Management Agency has been formed and a regional Disaster Management Agency has been formed. This agency is a Non-Departmental Government Institution that has the task of assisting the President in coordinating the planning and implementation of integrated disaster management and emergency activities, as well as implementing disaster management and emergencies starting from before, during and after a disaster which includes prevention, preparedness, handling emergency, and recovery (Presidential Regulation Number 8 of 2008 concerning the National Disaster Management Agency).

The role of the South Solok Regency government in dealing with earthquake disasters is to send a team of National Disaster Management Agency in the location of the earthquake affected area. The National Disaster Management Agency not only distributes logistical assistance and tents to the Solok Selatan community, but also handles psychological problems of children after the earthquake, namely by providing entertainment so that they can reduce the trauma caused by the quake, by inviting children to play, drawing and singing together. The Solok Selatan government also deployed a team of psychologists from the HB Saanin Mental Hospital, they contributed and had provided healing therapy to the earthquake victims, therapy was provided by traveling from one tent to another. The purpose of healing therapy is to give confidence to the community affected by the disaster, because the incident is the power of God and humans believe that life and life are arranged by God, the therapy given is not only for adults but also for children. After an interview with the local community they felt that the hilling therapy given to children was very helpful because the child who had felt very frightened and difficult to socialize could be cheerful again, but because therapy was only done in a few days, so the community thought that hilling therapy was lacking optimal, because only temporary psychological control of children.

\section{The Role of Non-Governmental Organizations (NGOs) in the Psychological Recovery of Children after the Earthquake Disaster in Solok Selatan}

According to Regulation Number 17 of 2013 concerning Community Organizations, NonGovernmental Organizations are one of the Community Organizations established by the community based on the common aspirations, desires, needs, interests of activities, and objectives to participate in development in order to achieve the goal of a unitary Republic of Indonesia based on Pancasila. The term NGO is defined clearly in the Instruction of the Ministry of Home Affairs No. 8/1990, which was addressed to governors throughout Indonesia regarding the Development of Non-Governmental Organizations. Appendix II of The Ministry of Home Affairs states that NGOs are organizations / institutions whose members are citizens of the Republic of Indonesia who voluntarily or independently intend to move in certain areas of activities determined by organizations or institutions as a manifestation of community participation in efforts to improve the standard of living and people's welfare.

Non-governmental organizations can be interpreted as organizations / institutions formed by community members Citizens of the Republic of Indonesia voluntarily on their own will and great interests and engaged in certain activities determined by organizations or institutions as a manifestation of community participation in efforts to improve the standard of living and people's welfare, which focuses on self-service (Africa, 2017). When a disaster occurs, NGOs also contribute to helping communities who are victims of disasters. The role of NGOs in handling natural disasters is to foster empathy and concern, mitigation education, and preparedness, organizing humanitarian volunteers, disaster response in the emergency phase, recovery and reconstruction, and community empowerment. This NGO organization can help the government to reduce the social problems that exist in Indonesia with the vision and mission of these NGOs that can educate us as human beings to have a sense of help and solidarity between people. After the disaster that took place in the southern district of Solok, NGOs in West Sumatra contributed to assisting the victims, contributing NGOs namely the Indonesian Volunteer Society of West Sumatera and the Aksi Cepat Tanggap Team (ACT) continued to coordinate with relevant parties to help evacuate disaster victims there, and helped restore psychological trauma experienced by children by inviting them to sing 
The Role of Costum in the Psychological Recovery of Children after the Earthquake Disaster in Solok Selatan

Costume can be explained as an act carried out repeatedly and then becomes a habit that is permanent and respected by people, so that habit becomes customary. Costume is habits that grow and form from a community or region that is considered to have value and is upheld and obeyed by its supporting community. Customs concern the attitude and behavior of someone who is followed by another person in a long time process. Customs or habits can be interpreted as a behavior that is continuously carried out in a certain way and followed by the outside community for a long time. Thus the elements of the creation of costume are the existence of a person's behavior, carried out continuously, the dimensions of time, and followed by other people/society. Thus custom is a rule that applies to a community, so that community members can adjust their actions to the behavior they make.

From the results of interviews conducted with one of the traditional stakeholders in the earthquake location in the southern district of Solok, it was found that several days after the earthquake a joint meeting was held between the niniak mamak, the ulama, clever people, and the local community who discussed opinions about the causes of the earthquake being a conversation of the local people (mystical), as the costume leaders they try so that the community does not have to believe this because in fact the earthquake occurred at the will of the almighty. In addition, costume stakeholders also provide good direction or coordination so that we can collaborate together in dealing with this post-disaster situation. And they are also involved together with the medical team namely pediatricians and psychologists by providing trauma healing therapy to help shape the character of traumatized children to be cheerful without fear of earthquakes by entertaining children and not leaving them alone. Indigenous leaders also give direction that do not make the earthquake a protracted sadness, of course we must rise. The direction of the costume stakeholders was positively welcomed by the community that we must unite and rise from this earthquake so that survival is maintained.

The Role of Universities in the Psychological Recovery of Children after the Earthquake Disaster in Solok Selatan

Higher education is a national asset in maintaining the development and sustainability of disaster knowledge and technology in Indonesia. In addition, universities are mediators to bring together various interests from the community, the Government and business institutions because they are considered neutral (Maarif, 2012). For this reason, BNPB has mobilized this power in the form of a university forum for disaster management. So that through this forum there will be a coordination and information exchange mechanism to disseminate and disseminate disaster management policies to fellow tertiary institutions, to the community, business institutions and the Government. In every major disaster event, universities are either asked or not, almost certainly will participate in providing assistance and conducting studies in various aspects. That is why BNPB synergizes the need for information based on scientific thinking with the scientific activities of universities in responding to disasters. With the knowledge possessed by students, both those obtained at the lecture level and in the organizational path, students can channel their abilities in the midst of society, and one of them is in handling disaster problems.

In West Sumatra, students who are members of several public and private campuses such as Andalas University, Universitas Negeri Padang (UNP), Putra Indonesia University, Bung Hatta University, and several other universities have taken many roles in disaster management. Many things that have been done, first, consolidate every student institution to hold a fundraising and use them, both those in West Sumatra, and those in Indonesia. Raising is done through institutions such as the Student Executive Board, Student Regiment, Scouts, Indonesia Red Cross, and several other institutions in their respective campus fields. Second, form a special disaster committee such as the Andalas Disaster Management Agency at Andalas University. Such institutions are very effective in handling disasters because they are gathered from various institutions that are experts in their respective fields, such as Student Executive Board, Student Regiment, Scouts, Indonesia Red Cross and others. Third, with existing institutions, the tasks are immediately divided according to the needs of handling the disaster itself. Starting from preparing logistics such as food, clothing, housing for the victims who were in the location of the disaster. This logistics is taken from the funds collected by students in various campuses throughout Indonesia. Fourth, make or compile a program that can 
be done to treat victims in disaster locations, both physically and mentally. What can be done by students in this case is to provide free medication or services, hold trauma healing for children and adults. In the aftermath of the earthquake that hit the south so many students from various universities from West Sumatra contributed to addressing the problems of the earthquake victims, one of which was students from UNP, UNAND, UPI, STKIP Alhusunah and others, one of them the type of assistance they provide is holding trauma healing for children in various ways, one of which is entertaining children by inviting them to draw, play, sing and tell stories.

\section{The Role of the Community in the Psychological Recovery of Children after the Earthquake Disaster in Solok Selatan}

Disaster management cannot be carried out alone by the Central Government or the Regional Government, this is because the situation that occurs because of the disaster is so difficult to handle so that it always needs a contribution from other parties to support it, both from the community itself. The thing that is highly expected by the government in the implementation of disaster management is the participation of the community itself. Because with public awareness, disaster management can be carried out more optimally. In handling disasters the role of the community becomes the most important element because the power of the government is only very small when compared with the challenges that are so great.

One way that can be used to encourage community participation is in the provision of funds. Collection of funds originating from the community is received and collected by the National Disaster Management Agency from the general public in private, group and / or groups, business institutions both from domestic and abroad voluntarily as grants to the State for disaster relief assistance needs in the entire territory of the Republic of Indonesia. Participation itself is also not limited to fundraising, but also direct participation in the form of sending disaster relief volunteers, goods, foods aid and equipment assistance. Post-disaster that occurred in the South Solok Regency, people from various regions in West Sumatra and provinces outside of West Sumatra also contributed to the psychological recovery of children by sending assistance in the form of toys, clothing, food and funds for these children.

\section{Conclusion}

The researcher concluded that the role of the government in the psychological recovery of children after the earthquake disaster was by sending BPBD teams and a team of psychologists to carry out emergency healing therapy, the role of NGOs in psychological recovery of children after the earthquake disaster by deploying several NGOs who contributed including the Indonesian Volunteer Society (MRI) team West Sumatra and the Act of Fast Response (act), the role of costume in the psychological recovery of children after the earthquake was attended by costume stakeholders, namely niniak mamak, the ulama and clever talents by giving direction so that we unite together to face disasters and restore children's psychological trauma anak kemanakan, the role of universities in the psychological recovery of children after the earthquake disaster is by involving several students from several universities in western Sumatra such as UNAND, UNP, UPI and others to help the psychological recovery of children by inviting them to play, draw. The role of the community in the psychological recovery of children after the earthquake disaster is by sending assistance in the form of toys, clothing, food and funds for children.

\section{References}

Afrika, M. 2017. Pengawasan Terhadap Lembaga Swadaya Masyarakat di Kabupaten Tulang Bawang Barat. Universitas Lampung.

Astuti, B. 2006. Konseling Anak Pasca Gempa Melalui Children Center. Makalah dalam Kegiatan Relawan Bencana Gempa Bumi Yogyakarta. Tanggal 10-17 Juni.

Enarson, E. 2000. Gender and Natural Disaster: Working Paper 1. Recovery and Reconstruction Departemen, Geneva. 
Hermon, D. 2009. Dinamika Permukiman dan Arahan Kebijakan Pengembangan Permukiman pada Kawasan Rawan Longsor di Kota Padang. Disertasi. IPB Bogor.

Hermon, D. 2010. Geografi Lingkungan: Perubahan Lingkungan Global. UNP Press.

Hermon, D. 2012. Mitigasi Bencana Hidrometeorlogi: Banjir, Longsor, Degradasi Lahan, Ekologi, Kekeringan, dan Puting Beliung. UNP Press. Padang.

Hermon, D. 2014. Impacts of Land Cover Change on Climate Trend in Padang Indonesia. Indonesian Journal of Geography. Volume 46. Issue 2. p: 138-142. Fakultas Geografi Universitas Gajah Mada.

Hermon, D. 2014. Desain Kebijakan Tanggap Darurat dan Pemulihan Bencana Letusan Gunung Sinabung. Seminar Nasional Geografi. Master Program of Geography Education, Universitas Negeri Padang.

Hermon, D. 2015. Geografi Bencana Alam. Jakarta: PT RajaGrafindo Persada.

Hermon, D. 2016. Mitigasi Perubahan Iklim. Rajawali Pers (Radjagrafindo).

Hermon, D. 2016. The Strategic Model of Tsunami Based in Coastal Ecotourism Development at Mandeh Regions, West Sumatera, Indonesia.Journal of Environment and Earth Science. Volume 6.

Hermon, D. 2017. Climate Change Mitigation. Rajawali Pers (Radjagrafindo).

Hermon, D., P. Iskarni., O. Oktorie and R. Wilis. 2017. The Model of Land Cover Change into Settlement Area and Tin Mining and its Affecting Factors in Belitung Island, Indonesia. Journal of Environment and Earth Science. Volume 7 No. 6. p: 32-39. IISTE.

Hermon, D., Ganefri., A. Putra and O. Oktorie. 2018. The Model of Mangrove Land Cover Change for the Estimation of Blue Carbon Stock Change in Belitung Island-Indonesia. International Journal of Applied Environmental Sciences. Volume 13. Issue 2. p: 191-202. Research India Publication.

Hermon, D., A. Putra and O. Oktorie. 2018. Suitability Evaluation of Space Utilization Based on Enviromental Sustainability at The Coastal Area of Bungus Bay in Padang City, Indonesia. International Journal of GEOMATE. Volume 14. Issue 41. p: 193-202. Geomate International Society.

Hermon, D. 2019. Evaluation of Physical Development of The Coastal Tourism Regions on Tsunami Potentially Zones in Pariaman City-Indonesia. International Journal of GEOMATE. Volume 17. Issue 59. p: 189-196. Geomate International Society.

Hermon, D., Ganefri, Erianjoni, I. Dewata, P. Iskarni and Alexander Syam. 2019. A Policy Model of Adaptation Mitigation and Social Risks The Volcano Eruption Disaster of Sinabung in Karo Regency-Indonesia. International Journal of GEOMATE. Volume 17. Issue 60. p: 190-196. Geomate International Society.

Kristian, A and O. Oktorie. 2018. Study of Coastal Mangrove Conservation in the World. Sumatra Journal of Disaster, Geography and Geography Education. Volume 2. Issue 1. p: 49-52

Kinchin, D. 2007. A Guide to Psychological Debriefing. London:Jessica Kingsley Publishers.

Maarif, S. 2012. Pikiran dan Gagasan Penanggulangan Bencana di Indonesia. Jakarta: Badan Nasional Penanggulangan Bencana.

Nilson, R, Gustafsson, P.E and Svedin, C.G. 2010. Self-Report Potentially Traumatic Live Events and Symptoms of Post-Traumatic Stress and Dissociation. NordicJournal of Psychiatry. 64, 19-26.

Oktorie, O. 2017. A Study of Landslide Areas Mitigation and Adaptation in Palupuah Subdistrict, Agam Regency, West Sumatra Province, Indonesia. Sumatra Journal of Disaster, Geography and Geography Education. Volume 1. Issue. 1. p: 43-49. Master Program of Geography Education.

Oktorie, O. 2018. Model Kebijakan Responsif Pemulihan Bencana Letusan Gunung Sinabung. Jurnal Kapita Selekta Geografi. Volume 1. Issue 1. p: 15-20

Rusmiati, C. 2012. Penanganan Dampak Sosial Psikologi Korban Bencana Merapi.Volume.17, No.02.

Soemantri, H. 2012. Strategi Pengarasutamaan Pengurangan Resiko Bencana Di Sekolah. Makalah disajikan dalam RapatKooordinasi Tim PengembanganKurikulum Propinsi dan Kabupaten/KotaSe Indonesia, Tanggal23-26 Juli di Hotel Mercure AncolJakarta. 
Triyatno, T., Ikhwan, and Febriandi 2018. Strategy for Community Adaptation in Facing Flood Natural Disasters in Pesisir Selatan District, West Sumatra. Sumatra Journal of Disaster, Geography and Geography Education, 2(2), 16-23. 